\title{
Konstruksi Sel Surya Bio menggunakan Campuran Klorofil-Karotenoid sebagai Sensitizer
}

\author{
Hafidz Bahtiar, ${ }^{1, *}$ Nur Aji Wibowo, ${ }^{1,2}$ dan Ferdy S. Rondonuwu ${ }^{1,2, \dagger}$ \\ ${ }^{I}$ Progam Studi Pendidikan Fisika, Fakultas Sains dan Matematika \\ ${ }^{2}$ Progam Studi Fisika, Fakultas Sains dan Matematika \\ Universitas Kristen Satya Wacana, Jln. Diponegoro No. 52-60 Salatiga 50711
}

Intisari

\begin{abstract}
Klorofil dan karotenoid merupakan pikmen yang digunakan oleh organisme fotosintetik sebagai pemanan cahaya. Klorofil dan karotenoid tersedia secara melimpah pada akar, batang, daun dan buah, maupun bakteri fotosintetik. Sebagai pemanen cahaya yang efisien, klorofil dan karotenoid dimanfaatkan sebagai sensitizer pada selsurya tersintesa pewarna menggunakan konstruksi Grätzel (Dye sensitized solar cell, DSSC). Kombinasi karotenoid dan klorofil sebagai sensitizer pada DSSC memungkinkan peningkatan efisiensi dibandingkan dengan sensitizer masing-masing pikmen tersebut. Penelitian ini melaporkan hasil konstruksi DSSC dengan menggunakan campuran $\beta$-karoten dan klorofil sebagai sensitizer. Campuran klorofil dan $\beta$-karoten mempunyai keluaran $\mathrm{V}_{o c}$ sebesar $14,1 \mathrm{mV}$ dan $\mathrm{J}_{s c}$ sebesar 5,76 $\mu \mathrm{A} / \mathrm{cm}^{2}$ dengan efisiensi mencapai $4,42 \times 10^{-5} \%$.
\end{abstract}

\begin{abstract}
Chlorophyll and carotenoid are pigments used by photosynthetic organisms as light harvester. Chlorophyll and carotenoids are abundantly available nature and can be found in the roots, stems, leaves, and fruit, as well as photosynthetic bacteria. As an efficient light harvester, chlorophyll and carotenoid may become potential candidate as sensitizers in dye sensitized solar cell using Grätzel construction (Dye sensitized solar cell, DSSC). The mixture of carotenoid and chlorophyll as sensitizers in DSSC may have higher efficiency than that of carotenoids or chlorophyll alone as sensitizers. This research reports the results of DSSC construction using a combination of $\beta$-carotene and chlorophyll as sensitizers. The combination of chlorophyll and $\beta$-carotene has $\mathrm{V}_{o c}$ output $14,1 \mathrm{mV}$ and $\mathrm{J}_{s c} 5,76 \mu \mathrm{A} / \mathrm{cm}^{2}$ with efficiency up to $4,42 \times 10^{-5} \%$.
\end{abstract}

KATA KUNCI: bio solar cell, chlorophyll, carotenoid, $\beta$-carotene

\section{PENDAHULUAN}

Dye Sensitized Solar Cell (DSSC) merupakan sel surya sederhana yang diusulkan pertama kali oleh Grätzel [1, 2]. Keunggulan DSSC dibandingkan panel surya konvensional adalah bahwa fabrikasinya lebih sederhana dan dapat dilakukan di luar clean room yang biasanya menjadi syarat fabrikasi panel surya konvensional. DSSC menggunakan dye sebagai material sensitizer yang dijadikan donor elektron pada partikel nano $\mathrm{TiO}_{2}$ dan menggunakan elektrolit sebagai medium transport elektron. Biasanya DSSC menggunakan ruthenium complex sebagai sensitizer, karena kemampuannya menyerap cahaya tampak dan menyuntikkan elektron pada nano partikel $\mathrm{TiO}_{2}$ [3]. Namun demikian penggunaan ruthenium complex masih dianggap mahal. Di lain pihak, pengetahuan tentang fotosintesis telah berkembang sangat jauh dimana material fotosintesis seperti pikmen klorofil dan karotenoid diketahui merupakan pikmen yang paling efektif pemanen foton dari matahari. Pengembangan DSSC

\footnotetext{
*E-MAIL: hafidz_fisikauksw@yahoo.com

$\dagger^{\dagger}$ E-MAIL: ferdyestaff.uksw.edu
}

menggunakan pikmen sebagai sensitizer menjadi pilihan yang cukup menjanjikan karena pikmen tersebut tersedia dalam jumlah melimpah di alam. Di samping kemampuan pikmenpikmen tersebut sebagai pemanen cahaya, pada kondisi tertentu pikmen-pikmen itu juga berfungsi sebagai elektron injector yang baik $[4,5]$. Dengan demikian penggunaan pikmen sebagai sensitizer pada DSSC akan menjadi relatif jauh lebih murah.

Pikmen yang dapat digunakan sebagai material sensitizer diantaranya adalah antosianin, klorofildan karotenoid. Klorofil yang diekstrak dari daun bayam (Amaranthus Hybridus L.) dan daun kacang panjang (Vigna sinensis) dapat digunakan sebagai material sensitizer. Bahkan, klorofil dari daun kacang panjang efisiensi konversi energi fotoelektrokimianya mencapai $2 \times 10^{-3} \%[6,7]$. Salah satu jenis karotenoid yang digunakan sebagai material sensitizer adalah $\beta$-karoten. $\beta$-karoten dari daun bayam telah berhasil digunakan dan campuran antara klorofil dan $\beta$-karoten dari sumber yang sama juga telah berhasil digunakan sebagai material sensitizer [8].

Paper ini melaporkan pembuatan prototipe DSSC dengan menggunakan tiga jenis pikmen sebagai material sensitizer. Klorofil dari daun katuk (Sauropus androgynus), $\beta$-karoten dari wortel (Daucus carrot L.), dan likopen dari tomat ( $L y$ copersicum esculentum) akan digunakan sebagai material sen- 


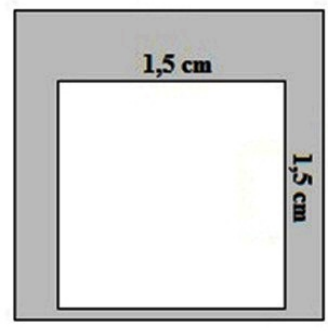

(a) Skema deposisi $\mathrm{TiO}_{2}$

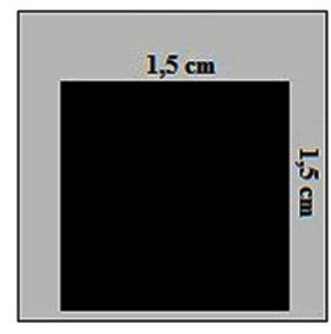

(b) Skema deposisi karbon
Gambar 1: Skema pelapisan a). $\mathrm{TiO}_{2}$, dan b). karbon pada kaca ITO [13].

sitizer. Selanjutnya, campuran antara karotenoid dan klorofil akan dicoba untuk mengetahui pengaruh dari masingmasing pikmen terhadap efisiensi konversi energi oleh DSSC. Campuran klorofil dan $\beta$-karoten digunakan karena campuran keduanya memberikan serapan maksimal terhadap spektrum sinar matahari dari 400-700 nm. Rondonuwu,dkk [9] menunjukkan transfer energi dari klorofil ke karotenoid terjadi cukup efisien, yaitu mendekati 90\%, untuk karotenoid dengan jumlah ikatan rangkap konjugasi 9 dan 10 yaitu neurosporene dan speheroidene. Namun turun secara signifikan dibawah $30 \%$ untuk karotenoid dengan jumlah ikatan rangkap konjugasi 11 atau lebih seperti likopen, anhidrorodovibrin dan spiriloksantin [9, 10]. Diketahui pula bahwa kompleks pikmen-protein (light-harvesting 2, LH2) pada bakteri fotosintesis yang tidak lain merupakan cincin karotenoid dan klorofil memberikan respons yang berbeda jika sebuah partikal $\mathrm{TiO}_{2}$ diletakkan di tengah cincin tersebut dan dipapar dengan cahaya. Ini mengindikasikan bahwa injeksi elektron pada $\mathrm{TiO}_{2}$ terjadi pada sistem kompleks pikmen-protein tersebut ketika sistem itu dipapar dengan cahaya [11]. Campuran karotenoid dan klorofil ini berpotensi menaikkan efisiensi DSSC jika sistem campuran ini digunakan sebagai sensitizer.

\section{METODOLOGI PENELITIAN}

\section{Ekstraksi pikmen}

Pikmen yang digunakan bersumber dari daun katuk, wortel, dan tomat. Klorofil diekstrak dari daun katuk, sedangkan karotenoid, $\beta$-karoten diperoleh dari ektraksi wortel (Daucus carrot L.) dan likopen diperoleh dari ekstraksi tomat (Lycopersicum esculentum). Daun katuk, wortel, dan tomat 20 gram diekstrak menggunakan pelarut aseton $100 \mathrm{ml}$ [7, 12]. Diaduk menggunakan shaker selama 1 jam, kemudian dimaserasi selama 24 jam. Ekstrak disaring dan disimpan dalam botol yang berlapis alumunium foil.

\section{Karakterisasi absorbansi pikmen}

Spektrum absorbansi masing-masing pikmen diukur dengan spektrofotometer UV-Vis (Optizen 2120 UV) pada

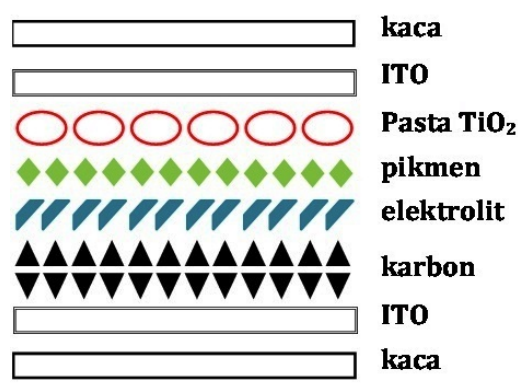

(a)

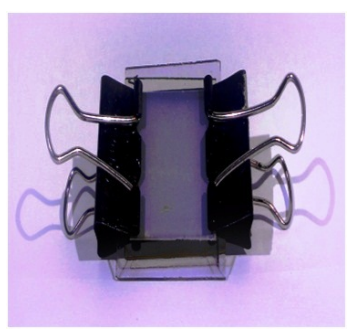

(b)

Gambar 2: a) Struktur sandwich prototipe DSSC, b) Hasil preparasi prototipe DSSC.

rentang panjang gelombang 400-700 nm. Dari hasil spektrum absorbansi, didapatkan informasi mengenai besar absorbansi atau optical density (OD) dari masing-masing pikmen. Total pikmen yang merupakan perkalian antara OD dengan volume larutan pikmen(V) akan menghasilkan optical density volume (ODV). Dalam penelitian ini perbandingan ODV ekstrak pikmen klorofil dengan pikmen karotenoid akan digunakan sebagai perbandingan campuran ekstrak pikmen klorofil dengan karotenoid untuk perendaman elektroda $\mathrm{TiO}_{2}$. Dalam penelitian ini digunakan perbandingan 1:1\%ODV.

\section{Preparasi elektroda $\mathrm{TiO}_{2}$}

Dalam preparasi elektroda titanium dioxide $\left(\mathrm{TiO}_{2}\right)$, tahap pertama adalah pembuatan pasta $\mathrm{TiO}_{2}$. Sebanyak 3,5 gram koloid $\mathrm{TiO}_{2}$ dilarutkan dalam $15 \mathrm{ml}$ etanol, dan diaduk dengan menggunakan magnetic stirrer selama 2 jam. Tahap kedua adalah membersihkan kaca berlapis Indium-tin oxide (ITO) dengan menggunakan aseton. Kemudian diukur resistansinya dengan menggunakan multimeter digital (fluke 179 EJKCT) dan selanjutnya pada sisi kaca ITO ditutup dengan menggunakan isolatipe seperti pada Gambar 1(a). Pasta $\mathrm{TiO}_{2}$ yang sudah tercampur homogen, dideposisikan pada kaca berlapis ITO dan kemudian dipanaskan dengan oven pada suhu $200^{\circ} \mathrm{C}$ selama 15 menit [7].

\section{Preparasi elektrolit}

Sebanyak $10 \mathrm{ml}$ polyethylene glycol (PEG) digunakan untuk melarutkan 0,8 gram potassium iodide (KI) dan 0,12 gram Iodine $\left(\mathrm{I}_{2}\right)$ untuk membuat elektrolit. Larutan elektrolit diaduk menggunakan magnetic stirrer selama 2 jam, kemudian disimpan dalam botol [7]. 


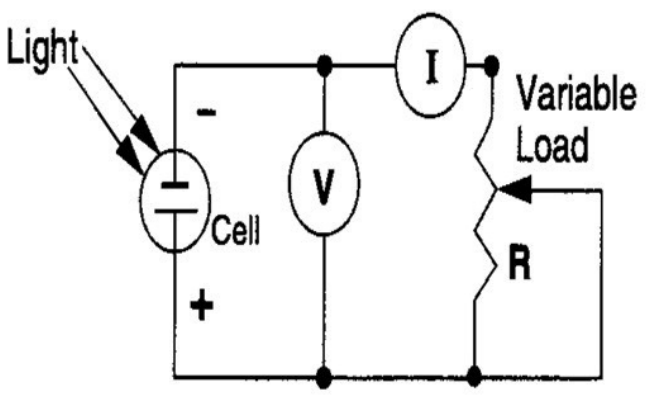

Gambar 3: Rangkaian pengujian DSSC [14].

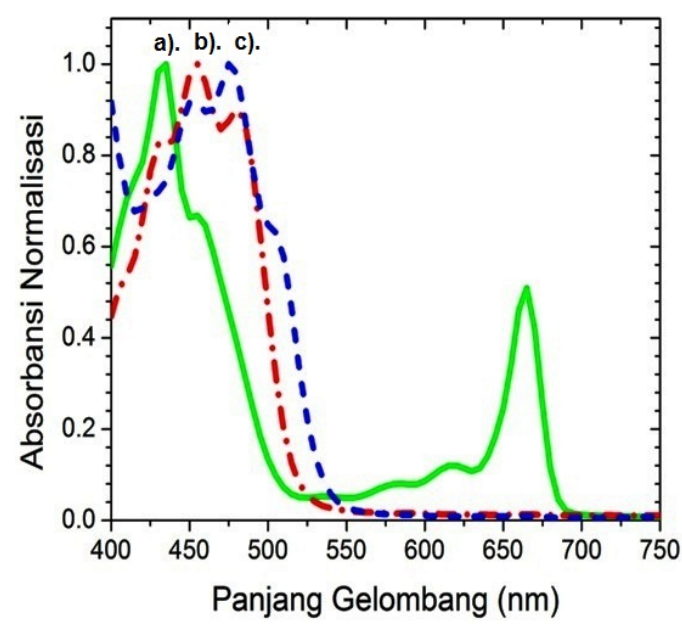

\section{Preparasi elektroda karbon}

Larutan karbon dibuat dari karbon (pensil 2B Staedtler)yang terlebih dahulu dihaluskan dengan mortar, kemudian diambil sebanyak 3,5 gram lalu dilarutkan ke dalam $15 \mathrm{ml}$ etanol. Larutan karbon diaduk menggunakan magnetic stirrer selama 2 jam. Kaca berlapis ITO dibersihkan dengan aseton dan diukur resistansinya menggunakan multimeter digital. Bagian tepi kaca berlapis ITO ditutup menggunakan isolatipe seperti Gambar 1(b). Selanjutnya kaca berlapis ITO dilapisi dengan larutan karbon dengan metode deposisi dan dipanaskan dengan oven pada suhu $200^{\circ} \mathrm{C}$ selama 15 menit [7].

\section{Pembuatan DSSC}

Elektroda $\mathrm{TiO}_{2}$ yang telah selesai preparasi, kemudian direndam selama 24 jam ke dalam ekstrak pikmen klorofil, $\beta$-karoten, likopen, serta campuran pikmen (klorofil $+\beta$ karoten), dan campuran pikmen (klorofil + likopen) dengan perbandingan 1:1\% ODV. Elektroda $\mathrm{TiO}_{2}$ yang telah direndam dalam pikmen, kemudian diangkat dan dikeringkan. Selanjutnya elektroda $\mathrm{TiO}_{2}$, dan elektroda karbon disusun dengan struktur sandwich DSSC seperti Gambar 2(a). Hasil pembuatannya seperti Gambar 2(b) dan diinjeksikan larutan elektrolit.

\section{Karakterisasi DSSC}

Prototipe DSSC yang telah dibuat, diukur arus dan tegangannya (I-V) dengan menggunakan multimeter digital untuk menganalisis karakteristik DSSC. Lampu Xenon $100 \mathrm{~W}$ dengan intensitas 500 lux dan dipasang pada jarak $25 \mathrm{~cm}$ digunakan sebagai sumber cahaya untuk pengukuran. Untuk mengatur arus dan tegangan (I-V) keluaran DSSC, maka dipasang resistor dengan berbagai variasi hambatan untuk mengetahui performa dari DSSC seperti Gambar 3.

Dari hasil pengukuran arus-tegangan (I-V), kemudian dapat ditentukan tegangan rangkaian buka $\left(\mathrm{V}_{o c}\right)$, tegangan maksimum $\left(\mathrm{V}_{\max }\right)$, rapat arus rangkaian pendek $\left(\mathrm{J}_{s c}\right)$, dan rapat arus maksimum $\left(\mathrm{J}_{\max }\right) . \mathrm{V}_{o c}$ dihasilkan ketika DSSC dalam keadaan rangkaian buka atau tidak ada arus yang mengalir

Gambar 4: Spektrum absorbansi normalisasi pikmen a). klorofil, b). $\beta$-karoten, dan c). likopen dalam pelarut aseton.

pada rangkaian pengukuran. $\mathrm{J}_{s c}$ dihasilkan pada saat DSSC dalam kondisi rangkaian pendek sehingga arus akan mengalir. Karakteristik yang mempengaruhi efisiensi DSSC adalah nilai faktor pengisian atau fill factor (FF) $[15,16]$. Nilai FF dapat dihitung dengan menggunakan persamaan:

$$
F F=\frac{J_{\max } \times V_{\max }}{J_{s c} \times V_{o c}}
$$

Untuk menghitung efisiensi konversi energi $(\eta)$ DSSC dapat dihitung dengan menggunakan Pers.(2). Perbandingan antara daya keluaran DSSC $\left(\mathrm{P}_{\max }\right)$ dan daya masuk dari sumber cahaya $\left(\mathrm{P}_{i n}\right)$ digunakan dalam perhitungan efisiensi konversi energi $(\eta)$ DSSC.

$$
\begin{aligned}
\eta & =\frac{P_{\max }}{P_{i n}} \times 100 \% \\
& =\frac{J_{s c} \times V_{o c} \times F F}{P_{i n}} \times 100 \%
\end{aligned}
$$

\section{HASIL DAN PEMBAHASAN}

Berdasarkan hasil pengukuran absorbansi dari masingmasing pikmen, didapatkan spektrum absorbansi seperti Gambar 4. Dari setiap pikmen mempunyai daya absorbansi maksimum (OD maksimum) yang berbeda-beda, yaitu pada panjang gelombang 430 untuk klorofil, $455 \mathrm{~nm}$ untuk $\beta$ karoten, dan $475 \mathrm{~nm}$ untuk likopen.

Prototipe DSSC dengan sensitizer pikmen klorofil, $\beta$ karoten, dan likopen yang telah difabrikasi, diuji karakteristik arus dan tegangan (I-V) dengan multimeter digital untuk mengetahui performanya. Hasil uji karakteristik kemudian dibuat grafik hubungan rapat arus terhadap tegangan $(\mathrm{J}-\mathrm{V})$ seperti ditunjukkan pada Gambar 5.

Dari kurva rapat arus terhadap tegangan $(\mathrm{J}-\mathrm{V})$ pada Gambar 5, diperoleh informasi bahwa masing-masing prototipe DSSC yang direndam dengan pikmen klorofil, $\beta$-karoten, dan likopen mempunyai karakteristik yang berbeda. Prototipe 


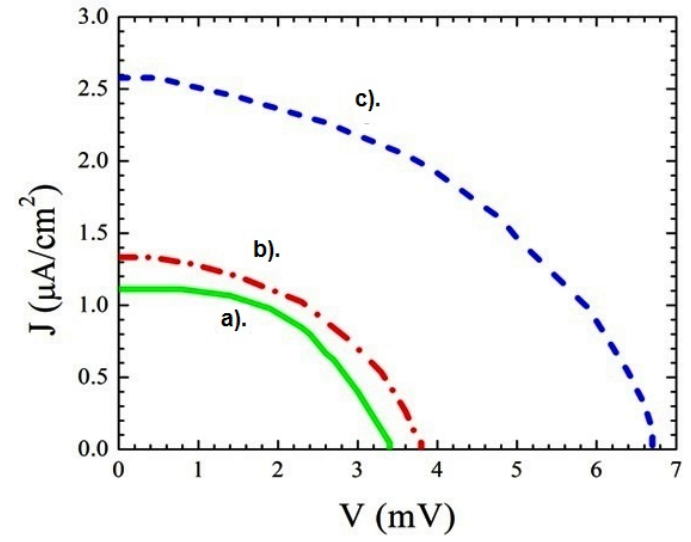

Gambar 5: Kurva Karakteristik J-V DSSC dengan sensitizer pikmen a). klorofil, b). $\beta$-karoten, dan c). likopen.

TABEL I: Karakteristik DSSC dengan sensitizer pikmen.

\begin{tabular}{lcccc}
\hline \hline Pikmen & $\begin{array}{c}\mathrm{V}_{o c} \\
(\mathrm{mV})\end{array}$ & $\begin{array}{c}\mathrm{J}_{s c} \\
\left(\mu \mathrm{A} / \mathrm{cm}^{2}\right)\end{array}$ & $\mathrm{FF}$ & $\begin{array}{c}\eta \\
\left(10^{-5} \%\right)\end{array}$ \\
\hline Klorofil & 3,40 & 1,11 & 0,51 & 0,17 \\
$\beta$-karoten & 3,80 & 1,33 & 0,46 & 0,21 \\
Likopen & 6,70 & 2,57 & 0,44 & 0,68 \\
\hline
\end{tabular}

DSSC dengan sensitizer pikmen likopen menghasilkan keluaran paling besar, yaitu dengan $\mathrm{V}_{o c}$ mencapai $6,70 \mathrm{mV}$ dan $\mathrm{J}_{s c}$ mencapai $2,57 \mu \mathrm{A} / \mathrm{cm}^{2}$. Prototipe DSSC dengan sensitizer pikmen klorofil menghasilkan keluaran yang paling kecil, yaitu dengan $\mathrm{V}_{o c}$ mencapai $3,40 \mathrm{mV}$ dan $\mathrm{J}_{s c}$ mencapai $1,11 \mu \mathrm{A} / \mathrm{cm}^{2}$.

Pada Tabel I terlihat bahwa prototipe DSSC yang direndam dengan menggunakan pikmen likopen memiliki efisiensi yang paling besar daripada yang lain, yaitu dengan efisiensi konversi energi mencapai $0,68 \times 10^{-5} \%$. Nilai efisiensi konversi energi $(\eta)$ dari DSSC dengan sensitizer pikmen klorofil mencapai $0,17 \times 10^{-5} \%$. Hasil tersebut masih terlalu kecil jika dibandingkan dengan yang diperoleh Anita, dkk dengan efisiensi konversi energi mencapai $2 \times 10^{-3} \%$. Perbedaan tersebut dapat terjadi karena faktor perbedaan sumber pikmen klorofil yang digunakan, dan intensitas cahaya yang dipakai untuk pengujian DSSC.

Tabel II menunjukkan perbandingan ODV masing-masing pikmen. Selanjutnya dilakukan fabrikasi DSSC dengan campuran pikmen (klorofil $+\beta$-karoten) dan (klorofil + likopen) sebagai material sensitizer. Dimana masing-masing campuran pikmen dicampurkan dengan perbandingan 1:1\%ODV.

Hasil pengukuran absorbansi dari campuran pikmen (klo-

TABEL II: Perbandingan ODV pada masing-masing pikmen.

\begin{tabular}{lccc}
\hline \hline Pikmen & $\begin{array}{c}\text { Klorofil } \\
(\mathrm{ml})\end{array}$ & $\begin{array}{c}\beta \text {-karoten } \\
(\mathrm{ml})\end{array}$ & $\begin{array}{c}\text { Likopen } \\
(\mathrm{ml})\end{array}$ \\
\hline ODV $(\mathrm{ml})$ & 118,98 & 164,02 & 88,24 \\
Klorofil + $\beta$-karoten & 1,0 & 1,4 & - \\
Klorofil + likopen & 1,4 & - & 1,0 \\
\hline \hline
\end{tabular}

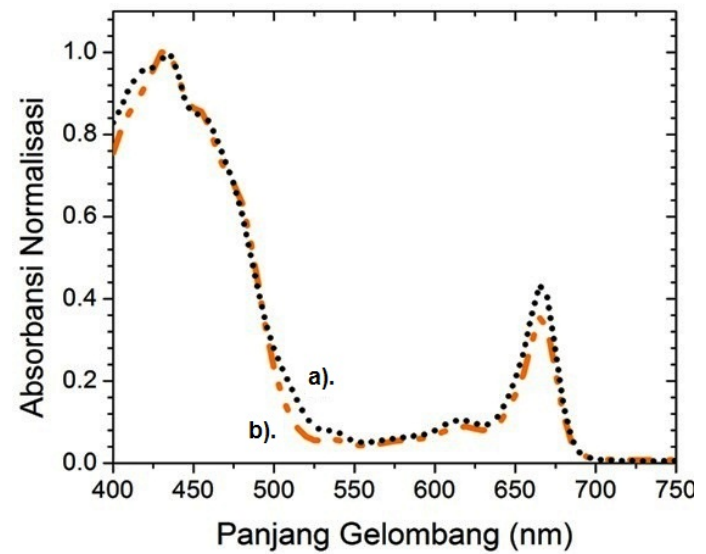

Gambar 6: Spektrum absorbansi normalisasi campuran pikmen a). (klorofil + likopen), dan b). (klorofil $+\beta$-karoten) dalam pelarut aseton.

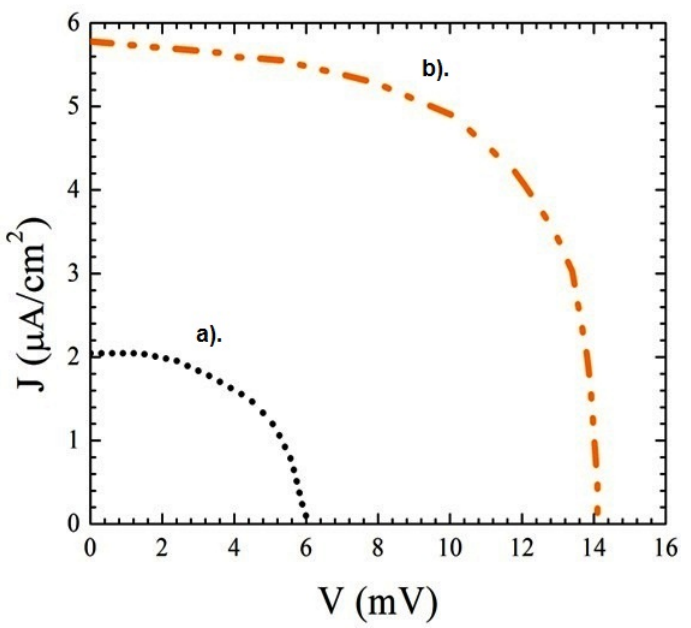

Gambar 7: Kurva karakteristik J-V DSSC dengan sensitizer campuran pikmen a). (klorofil + likopen), dan b). (klorofil $+\beta$-karoten $)$.

rofil $+\beta$-karoten) dan (klorofil + likopen) mempunyai daerah absorbansi yang hampir sama, namun OD maksimumnya berbeda. OD maksimum dari campuranpikmen terdapat pada panjang gelombang $430 \mathrm{~nm}$ untuk campuran pikmen (klorofil $+\beta$-karoten) dan $435 \mathrm{~nm}$ untuk campuran (pikmen klorofil+likopen). Prototipe DSSC dengan campuran pikmen (klorofil $+\beta$-karoten) dan (klorofil + likopen) yang telah difabrikasi, kemudian diuji karakteristik arus dan tegangan (I-V) untuk mengetahui performanya. Hasil uji karakteristik kemudian dibuat grafik hubungan rapat arus terhadap tegangan (JV) seperti ditunjukkan pada Gambar 7. Dari kurva rapat arus terhadap tegangan ( $\mathrm{J}-\mathrm{V}$ ) pada Gambar 7, diperoleh informasi bahwa dari campuran pikmen (klorofil $+\beta$-karoten) dan (klorofil + likopen) mempunyai karakteristik yang berbeda.

Dari kedua DSSC dengan campuranpikmen yang berhasil difabrikasi, karakteristik keluaran yang paling besar dihasilkan oleh prototipe DSSC dengan campuran pikmen (klorofil $+\beta$-karoten) seperti terlihat pada Tabel III. Hasil keluarannya, yaitu $\mathrm{V}_{o c}$ sebesar $14,1 \mathrm{mV}$ dan $\mathrm{J}_{s c}$ sebesar 
TABEL III: Karakteristik DSSC dengan sensitizer campuran pikmen.

\begin{tabular}{lcccc}
\hline \hline Pikmen & $\begin{array}{c}\mathrm{V}_{o c} \\
(\mathrm{mV})\end{array}$ & $\begin{array}{c}\mathrm{J}_{s c} \\
\left(\mu \mathrm{A} / \mathrm{cm}^{2}\right)\end{array}$ & FF & $\begin{array}{c}\eta \\
\left(10^{-5} \%\right)\end{array}$ \\
\hline Klorofil + $\beta$-karoten & 14,1 & 5,78 & 0,61 & 4,42 \\
Klorofil + Likopen & 6,0 & 2,04 & 0,53 & 0,58 \\
\hline \hline
\end{tabular}

$5,76 \mu \mathrm{A} / \mathrm{cm}^{2}$. Nilai efisiensi konversi energi dari prototipe DSSC yang direndam dengan campuran pikmen (klorofil $+\beta$ karoten) mencapai $4,42 \times 10^{-5} \%$. Hal tersebut menunjukkan bahwa dengan campuran pikmen (klorofil $+\beta$-karoten) dapat meningkatkan hasil keluaran dan efisiensi dari DSSC. Perbedaan efisiensi antara campuran klorofil dan $\beta$-karoten dibandingkan dengan campuran klorofil dan likopen kemungkinan disebabkan oleh kemampuan transfer energi eksitasi $\beta$ karoten ke klorofil lebih efisien ketimbang likopen ke klorofil $[9,10]$. Rendahnya transfer itu kemungkinan disebabkan oleh posisi tingkat energi singlet klorofil yang dikenal dengan pita $\mathrm{Q}_{y}$ berada relatif lebih tinggi daripada tingkat energi singlet likopen yaitu pita $2 \mathrm{Ag}^{-}$. Tingkat energi singlet karotenoid $2 \mathrm{Ag}^{-}$adalah salah satu tingkat energi yang paling bertanggung jawab terhadap transfer energi eksitasi antara karotenoid dan klorofil $[9,10]$

\section{SIMPULAN}

Telah berhasil dilakukan fabrikasi prototipe DSSC menggunakan pikmen klorofil, $\beta$-karoten, dan likopen. Prototipe DSSC menggunakan campuranpikmen (klorofil $+\beta$-karoten) dan (klorofil + likopen) telah berhasil difabrikasi. Hasilnya, campuran pikmen (lorofil $+\beta$-karoten) mempunyai keluaran yang lebih baik, dengan $\mathrm{V}_{o c}$ sebesar $14,1 \mathrm{mV}$ dan $\mathrm{J}_{s c}$ sebesar $5,76 \mu \mathrm{A} / \mathrm{cm}^{2}$, dan efisiensi konversi energinya sebesar $4,42 \times 10^{-5} \%$. Interaksi pikmen klorofil dengan $\beta$-karoten berhasil meningkatkan meningkatkan keluaran dan efisiensi dari DSSC.
[1] M. Grätzel, Journal of Photochemistry and Photobiology, 4, 145153 (2003).

[2] M. Grätzel, C.R. Chimie, 9, 578-583 (2005).

[3] A. Maddu, M. Zuhri, dan Irmansyah, Makara, Teknologi 11(2), 78-84 (2007).

[4] X.F. Wang, et al., Chemical Physics Letters, 416, 229-233 (2005).

[5] J. Xiang, et al., J. Phys. Chem. B, 109, 17066-17077 (2005).

[6] M.S.W. Kumara, dan G. Prajitno, Studi Awal Fabrikasi Dye Sensitized Solar Cells (DSSC) dengan Menggunakan Ekstraksi Daun Bayam (Amaranthus hybridus L.) sebagai Dye Sensitizer dengan Variasi Jarak Sumber Cahaya pada DSSC, Laporan Penelitian, Institut Teknologi Sepuluh November, Surabaya, 2012.

[7] Anita, dkk., Karakteristik Klorofil Pada Daun Kacang Panjang (Vigna sinensis) sebagai Dye-Sensitized Solar Cells, Seminar Nasional $2^{\text {nd }}$ Lontar Physics Forum 2013 LPF 1353.

[8] E. Barnoy, et al., The Potential Of Natural, Photosynthetics Pigments to Improve The Efficiency of Dye-Sensitized Solar Cells, Thesis M. Sc, University of Maryland, 2011.

[9] F. S. Rondonuwu, et al., Chemical Physics Letters, 390, 314-322
(2004).

[10] J. Akahane, et al., Chemical Physics Letters, 393, 184-191 (2004).

[11] X. H. Chen, et al., Biophysical Journal, 88, $4262-4273$ (2005).

[12] A. Umoro, Sukoso, dan Yahya, Pengaruh Jenis Pelarut Dan Lama Ekstraksi Yang Berbeda Terhadap Mutu Karotenoid Dan Aktivitas Antioksidan Karotenoid Dari Limbah Udang (Litopenaeus vanname), Laporan Penelitian, Universitas Brawijaya, Malang, 2010.

[13] M.C. Misbachudin, S. Trihandaru, A. Sutresno, Jurnal Fisika dan Aplikasinya, 10(2), 57-62, 2014.

[14] R. Kholid, dan A. Syafsir, Pengaruh Hubungan Seri-Paralel Pada Rangkaian Sel Surya Pewarna Tersensitisasi (SPPT) Terhadap Efisiensi Konversi Energi Listrik, Laporan Penelitian, Institut Teknologi Sepuluh November, Surabaya, 2009.

[15] T. Marinado, Photoelectrochemical studiea of dye sensitized solar cells using organic dyes, Kungliga Tekniska Hgskolan, Stockholm, 2009.

[16] K. Wongcharee, V. Meeyoo, and S. Chavajed, Solar Energi Materials and Solar Cells, 9, 566-571 (2007). 